\title{
Donne's Model: Henry IV
}

\section{ANTHONY RASPA}

Summary: Donne's Pseudo-Martyr is his first major published work and the longest that he ever wrote. As he argues in it about the relationship of the state and religion to each other, he establishes Henry IV of Navarre, king of France, as one of his models of a competent and tolerant king. Henry's credentials for the title are his moderation, his steadfastness and fearlessness amid religious conflicts between Catholics and Protestants in his own country, and in the face of the power of the papacy. In the pages of Pseudo-Martyr, Donne calls upon the English Catholics to swear allegiance to James I as a political leader, in the same manner in which French Catholics and Protestants swore allegiance to Henry.

\section{$J^{2}$}

ohn Donne wrote Pseudo-Martyr in 1609. When he published it in January of 1610 , four months before Henry of Navarre's assassination, it was the first of his works to appear in print. Except for a few prefatory poems that he published in other people's works, Pseudo-Martyr, which explores the realms of regicide, royal allegiance, religious conversion and the nature of church and state, therefore marked his debut as a published author. ${ }^{1}$

Pseudo-Martyr is an unusual work for a man, whose reputation has been principally that of a poet, to have chosen to introduce himself to the reading public. But its central issues of regicide and allegiance to the monarch were pivotal to his own life and to the English-Catholic public to which he ostensibly addressed the work. Pseudo-Martyr, therefore, covers a wide field of private and public issues, including religion, religious conversion, Donne's own, from Catholicism to Protestantism, the power of the pope, the origins of the power of the secular ruler and his relationship to his people, the relationship of the pope to Catholic and Protestant rulers, the duty of a Catholic subject to a Protestant king and of a Protestant subject to a Catholic king with reference to Henry of Navarre among others, Jesuits, church and secular courts, how to assassinate a king and not get caught, and how to 
assassinate a king and what does the would-be assassin do if he fails and manages to escape. All of these topics fill the longest work by far that one of Britain's major Renaissance poets unleashed on a British reading public, at the same time, moreover, that Shakespeare was bidding farewell to the stage between 1609 and 1611, with The Tempest, The Winter's Tale and Cymbeline, plays about rulers, often members of the same family, drowning, robbing, exiling and betraying one another.

However, there is something yet more striking about Pseudo-Martyr than its subject. As an exercise in history, we could replace Donne's name by Henry IV of Navarre's and we would discover that the two men were interested in similar public issues in which their respective lives at the moment were bound up. Consequently, in Pseudo-Martyr, Henry IV King of France, he who elsewhere has been described as either a supreme cynic or just eminently practical, the man who is reputed to have said that Paris was worth a Mass and who may be considered to have thought that God was worth the throw of dice, ${ }^{2}$ the Renaissance man who gave his name to one of the principal autoroutes of Quebec City (and this is not said facetiously, as it bespeaks the vitality of his reign), the individual in whose name Champlain founded the first permanent settlements of the already founded New France and who gave birth to the historical puzzle that we are still trying to put together, this man is discovered in Pseudo-Martyr as one of John Donne's background models for his work. This fact is surprising and difficult to believe only without reflection. For what Pseudo-Martyr was concerned with when Donne published it was of general concern across the face of Western Europe. Were not the numerous assassinations of kings and queens in the Renaissance, by their subjects and by one another, as reflected in Shakespeare's last plays, a sign of how Europe's absolute monarchs came to cope with the first lifting of the constraints that had once been imposed upon them by the rules of the old medieval world order? Once the medieval hierarchies waned, leaving the rungs of their social and political ladder in place -- kings, queens, princes, knights and so forth -- but without any cement of the fealty of vassals among them, and before Parliaments developed their own independent constitutional rules, the monarchs of Europe, so long as they had the military force to back up their power, had relative liberty to seek what they wished. A bright happy period might be considered to have existed for monarchs when relatively little could impede the fulfillment of their desires, including killing one another, providing they had financial and other resources to fulfill them.

Perhaps from the point of view of someone in literature, if not in history or political science, the order of government in at least the first phase of the 
Renaissance appears to have been the feudal system with few of its rules and duties. One has only to consider the complete disappearance of the EnglishCatholic hierarchy by 1600 . The perception may seem simplistic, but that is the picture of political power that creative literature seems to project. Whoever was born into position had power but there appears to have been few intrinsic rules of loyalty between those who wielded power and the governed. To all practical intents and purposes, the metaphysical and religious order by which the rungs of the medieval political and social hierarchy had been held in place no longer existed. The pope in the person of Paul V who was still at the top of the ladder could blatantly issue two briefs, in 1606 and $1607,{ }^{3}$ telling good English-Catholics that in the name of Christ they were quite justified to assassinate James I, the son of the politically executed Catholic Mary Stuart, because he was a Protestant. On political grounds Paul's briefs were strongly attacked, through legal and political precedents. However, no one challenged the religious morality of Paul's incitation, not even Donne, ${ }^{4}$ until Cardinal Giovanni-Battista Montini in the early 1960s, three and a half centuries later, took the title of Paul VI in a fruitless attempt to undo what Paul V had done.

In Pseudo-Martyr, Donne questions the political morality of the earlier Paul's briefs with vehemence and invective, but references to the Mosaic interdiction to kill are absent there as in the rest of the regicide debate. Elsewhere, in France, any number of plotters belonging to the Catholic League were free without compunction to consider assassinating Henry III, in which they succeeded, and Henry IV, in which, after a number of failed attempts, they or somebody else succeeded depending on whether or not the Queen (Marie de Médicis) was really in on the plot,,$^{5}$ and depending of course on whether Henry IV was Catholic, or Protestant, or both, or neither: historians do not seem to have pronounced themselves on the matter with finality. ${ }^{6}$

The role of Henry IV as a background model begins early in PseudoMartyr. However, to understand this model, it must be remembered that Henry was a Protestant brought up by a Protestant mother and that he later became head of the Calvinist Party in France. Then, he saved his life in the Saint Bartholomew's Day massacre by abjuring Protestantism, he became heir to the throne with the convenient death of Henry III's brother, which agitated the Catholic side, and when a monk assassinated Henry III, he became king. But the process by which he came to solidify his power over his throne was complex. When he became the new heir apparent on the death of Henry III's brother, the then Pope Sixtus V sided with the objectors in the persons of radical French Catholics to this would-be Protestant monarch, and the French Protestant François Hottoman issued in behalf of the heir-apparent 
Henry his "Brutum fulmen Papae Sixti V", or the brutish fulmination of Pope Sixtus V. It is to the general historical incident and to Hottoman's defense of Henry, through his references to Hottoman's writings against religious tyranny, that Donne refers to as early as the opening pages of Pseudo-Martyr (p. 11). ${ }^{7}$

The parallel on the one hand between Henry, King of France, the Protestant son of a Protestant mother, who became a Catholic king and who managed to pacify the papacy, and on the other hand the English king, James I, the Catholic son of a Catholic mother, who was brought up a Protestant and became a Protestant king, but with whom the pope would make no peace, could have hardly escaped the contemporary mind. Henry IV serves Donne as a model of the ruler to whom English Catholics as well as Protestants could certainly swear allegiance, in the manner in which French Catholics as well as French Protestants came to swear allegiance to Henry, if only the pope came to accept James as rightful king of England. In his original objections to the legality of Henry's monarchy, Sixtus had declared that Henry had forfeited his rights to the throne of France for not being hostile to heresy and not guaranteeing Catholicism to his future kingdom. He even deprived him of his crown of Navarre. Of course, Henry continued to reign. But only a few years later, Henry made peace with Sixtus' successor Gregory IV. ${ }^{8}$ The basis of Donne's argument in Pseudo-Martyr is that this sort of accommodation between Henry and Gregory is also possible between pope and English king and English Catholics. It is the papacy that Donne urges to move once more.

The background model role that Donne bestows on Henry surfaces yet more explicitly than in the citations from Hottoman only a few pages later in his work. There, the attention is on the negotiations that Cardinals Jacques Davy Duperron and Cardinal François de Joyeuse conducted on Henry's behalf to attenuate the crisis over legal jurisdictions and land claims between the Venetian Republic and the same Paul V who was quarreling with James. ${ }^{9}$

The Venetian crisis, as it came to be known, reached its zenith in 1605 and 1606, the years but one in which Paul issued his briefs against James, and was threatening to break out into open conflict. This time the Donne who speaks in Pseudo-Martyr is much less the lawyer, the ex-law student of Thavies' Inn and Lincoln's Inn in London, who referred to Hottoman's Protestant arguments earlier, and he is much more Donne the diplomat and soldier who accompanied Essex on his expeditions in the last years of Elizabeth's reign and who went on missions to the Continent alone for James, some years later. As Donne lays his case before English Catholics in PseudoMartyr, he admires the delicacy and firmness with which Henry and his two 
representatives, Duperron and de Joyeuse, negotiated peace between the papacy and the Venetian republic. He writes:

And not to speake of the Kingdome of France at this time, because I have sepos'd and destin'd a particular Chapter for that consideration [at the end of Pseudo-Martyr], nor of the fresh Historie of the Venetians, maintaining their just Lawes for this temporall Jurisdiction: which lawes Parsons, [Robert, the Jesuit], without any colour of truth, or escape from malitious and grosse deceiving, sayes they have recalled, when as (not to affright you with any of those Authours which write on the Venetian part,) you may see an excellent relation of that negotiation, and upon what conditions the Pope withdrew his censures, in that letter of Cardinal Peron to his Master the French King, about Cardinal Joyeuse his instructions, when the Pope sent him to Venice for that purpose (p. 15).

Donne refers to the background of the Venetian crisis, as though it were a legal precedent for the pope's toleration of James' Protestantism. This background is fraught with events that, if we had been alive and reading in 1610 , we would have immediately understood. Henry emerges from Donne's handling of the Venetian crisis as a silent retiring hero. From the English side of the channel, in Donne's eyes, Henry of Navarre appears as a monarch who has been maligned by French extremists, Catholic and Protestant alike, who has finally come to rule over them and his supportive political centrists too with a semblance of internal peace for his country, who has himself made peace with the papacy, and who has now the time to try to settle most generously the problems of his once most powerful enemies in Rome. The Swiss-born career diplomat Duperron of Donne's reference was now a Cardinal but he had been born a Calvinist who converted to Catholicism in the late 1570s and entered Holy Orders. A firm friend of Henry IV, he became his chargé d'affaires in Rome and was created Cardinal there in 1604. With that other Cardinal of Donne's reference, de Joyeuse, who also represented Henry, in Venice and Rome, Duperron negotiated peace between the Doge Leonardo Dona and Paul V. Paul sent Cardinal de Joyeuse to Venice with a list of conditions for lifting the excommunication against the city; de Joyeuse reported back with the answer, and, as a result of de Joyeuse's report, Duperron wrote his extraordinary letter of 5 April 1607 to Henry in Paris, describing in human as well as diplomatic detail, the meeting between de Joyeuse and the Pope. ${ }^{10}$

Not the least of the Venetian demands, as Donne reminds his EnglishCatholic readers, was that the Jesuits continue to be banished from their state, which anyone who read the letter would know was also true to be the case in 
England and once in France as well. Can the Protestant James be so bad, Donne asks with his model of Henry, if a Catholic doge of Venice and a Catholic king of France can allow Jesuits to be banished too? ${ }^{11}$ If the publication of diplomatic letters was a form of mass media output for conducting wars, Duperron's letter to Henry describing the negotiations between de Joyeuse and the Venetians aimed at influencing international public opinion, in a manner similar to the allied use of a new-wide screen Nintendo coverage in the recent Gulf War. Coming as it did from an ex-Calvinist turned Catholic, Duperron's letter to Henry was immediately held to be of profound historical importance, and it was published in three languages, French, Italian and Latin, in a large volume of mainly political and diplomatic addresses to kings entitled Monita Politica in Frankfurt in $1609 .{ }^{12}$ The volume of addresses was supposedly threaded by the common theme of the immense power of the Roman curia, it circulated widely throughout Europe, and Donne had a copy that he cites numerous times in Pseudo-Martyr.

But the "mediatic Nintendo war" conducted through that printed letter had even more subtle ramifications than that of political reconciliation, with or without Jesuits, that we in the present day could have hardly ignored if we had been looking at its wide screen in the seventeenth century. The recipient of the letter, Henry of Navarre, who must have allowed its publication, and Cardinal Duperron, who wrote it, could not have ignored these ramifications less than Donne did as be composed Pseudo-Martyr. For the fact was that Duperron, the ex-Calvinist, had negotiated Henry IV's conversion with Pope Clement VIII. Moreover, he had conducted this conversion without giving in to the pope's insistence for the reinstallation of the Jesuits in France. And if that did not flash bright enough on the "Nintendo screen" of the coverage of the war between James and Paul V in the pages of Pseudo-Martyr, most of Donne's English-Catholic audience to whom he was pleading for their allegiance to James, would have also known of an earlier historical link between Duperron and James Stuart. At the death of Mary Stuart, James' mother, Duperron had delivered in Paris a spectacular oration describing her personal and royal virtues. Therefore Duperron, de Joyeuse, Donne, all conciliatory men following in the footsteps of one of Pseudo-Martyr's background models, Henry of Navarre, were asking English Catholics to see reason.

What remains of Henry of Navarre in Pseudo-Martyr is now due less to reasons of the head than to political causes and to John Donne himself. For Henry of Navarre is present, and also absent, from Pseudo-Martyr in two other ways in which only Donne could have caused him to be. The first of 
these ways is in Donne's reference twice in Pseudo-Martyr to the attempted assassination in which Henry lost a tooth instead of his life. In the facetious, satiric mode that twentieth-century English literature came to like in his poetry, Donne revels however briefly in Henry's failed assassination. In the morning in his mistress's apartment, a newly-risen king, fresh out of bed, receives his courtiers. The king, whom most historians tend to describe as personally a pleasant individual, bends down to help one of his courtiers off the floor. But he stoops at the very moment that a young man who is a student in a Jesuit college tries to stick a knife into his chest. The young man hits the bent figure in the mouth instead of in the chest and he knocks out one of his teeth. The young man; Jean Chastel, is said to confess that his Jesuit teachers told him to kill the king for God and country, and he is quickly hanged as well as is one of his teachers. For Donne, who loves to mix satire with high serious political discussion, there is no limit to how confined the power of Jesuits can be.

And yet this hater of Jesuits and Catholicism loved them too much ever to leave them alone. For there is a whole second-to-last chapter on Catholic France and the justification of papal power in France, and a last chapter on England's conversion to Roman Christianity at the end of the sixth century, that Donne never wrote. In his "Advertisement to the Reader" prefaced to Pseudo-Martyr (p. 8), he tells us that he had planned fourteen chapters for the work, and, in his table of contents, he in fact lists all of them; chapter thirteen was to deal with the French oath of allegiance that all Frenchmen took to their Catholic king, and chapter fourteen with the political independence of England from the papacy in spite of its sixteenth-century conversion to Roman Christianity. But he adds that he never wrote these last two chapters because those of his friends among whom he had circulated his table of contents while he was writing the work objected to them. Pseudo-Martyrends abruptly with chapter twelve. Defiantly, it seems, Donne did not remove the titles of the missing chapters from his table of contents when he published the work. Donne develops in the last actually written chapters of Pseudo-Martyr a theory of papal power and royal secular power that separates them.

His theory, which would have found its natural conclusion in the examples of the two unwritten chapters, makes it possible for the subject of one king to adhere at will to the king's religion, or to adhere to the religion of another kingdom. That is, an English-Catholic could swear allegiance to James as secular ruler and yet also swear allegiance to the pope's spiritual authority without contravening either source of secular jurisdiction at home or religious jurisdiction abroad. Similarly, a Frenchman could swear fealty 
to his king in France and adhere to the religion of the king in England. The last two chapters of Pseudo-Martyr were to give historical examples of this theory at work. In chapter thirteen dealing with France, the illustration would have been of the present day. In chapter fourteen, the example would have been drawn from the past when the Italian Augustine of Canterbury converted Ethelbert, King of Kent, to Roman Catholicism in 597.

In his "Advertisement to the Reader," Donne tells us that his friends particularly objected to the projected chapter fourteen about England's conversion to Christianity. He writes that they really never told him why they objected to either chapter thirteen or fourteen, that the chapters were too closely tied up for him to think of writing one without the other, and that in effect he would not write either to avoid offending those friends of his, particularly because he supposedly ignored even at the moment of the publication of the work the grounds for their opposition (p. 9). Of course, John Donne, one of English Renaissance literature's most lonely mavericks, to whom his friend James I systematically denied secular preferment, and who never made him in the Anglican Church more than Dean of Saint Paul's, could not have been so stupid. In his "Advertisement to the Reader" what Donne says is really nothing but tongue-in-cheek diplomatic evasion that tells much. After all, the text of Pseudo-Martyr had to get by the licensing of the Stationer's Register. That Donne allowed the titles of chapters thirteen and fourteen to be published in the table of contents, while supposedly apologizing for them in the "Advertisement," was his way of rejecting the arguments of his beloved friends. If Donne was too intellectually wide-minded for the pope, he was so as well for his English Protestant friends. For, by showing in chapter thirteen how conveniently his theory of international allegiances was, according to him, working in present-day France of Henry of Navarre, ${ }^{13}$ and in chapter fourteen how well it had worked, at least for a while, when Augustine brought the kingdom of Kent out of paganism into the Roman fold, in the "Nintendo war" context of its day, Pseudo-Martyr would have ended up implicitly inviting the whole of England back into the see of Rome. Explicitly, Donne's work could even be seen as subverting its declared aim of defending James against Paul's assassination briefs.

All of these political manoeuvres about Donne's intentions in his work produced a great loss for our present day. When Donne decided not to write chapter thirteen because he was not writing chapter fourteen, he also denied us a full picture of Henry of Navarre. But we have a glimmer of what chapter thirteen would have contained in Donne's first reference to Cardinals Duperron and de Joyeuse and Henry of Navarre in the early pages of the work. In 
those early pages, Donne tells us he will deal with the cardinals and the king now only passingly and that he is reserving his fuller comments for his chapter on France later. But the nature of his early references is fraught with political suggestions about the nature of the church and state. The thirteenth chapter would have undoubtedly developed these suggestions and shown states and churches everywhere living in contemporary harmony. Pseudo-Martyr therefore leaves us only a shadow of Donne's high esteem for Henry IV of France. The shadow is however long enough to point to the values that Donne would have us partake with France's moderate, conciliatory Gallican leader.

\section{Université Laval}

\section{Notes}

1. The prefatory poems are "Amicissimo et meretissimo Ben: Ionson" in the 1607 edition of Volpone, and "The Expiration" in Alfonso Ferrabosco's book of Ayres in 1609. The edition of Pseudo-Martyr used here is that edited by Anthony Raspa (Kingston/Montreal: McGill-Queen's University Press, 1993).

2. On Henry IV's religion, see: M. Wolfe. The Conversion of Henri IV (Cambridge, MA: Harvard University Press, 1993).

3. "Introduction," Pseudo-Martyr, p. xxxii.

4. What is in question here are not the political grounds of the pope's interference but the lack of reference to the Decalogue as an element in political murders.

5. Insofar as Henry IV's assassination is concerned, Ravaillac, the king's assassin, always maintained even under torture that he had acted alone: R. Mousnier. The Assassination of Henri IV (New York: Scribner's, 1973), p. 29.

6. Recently, R. Love in "The Religion of Henry IV: Faith, Politics, and War, 1553-1593" (Ph.D Dissertation, University of Southern California, 1986) has contended that Henry was a convinced Protestant when he nevertheless adhered outwardly to Rome in 1593, but other historians like M. Wolfe (The Conversion of Henri IV, p. 123-5) disagree.

7. Hottoman, author of Francogallia (1573) on state liberty in pre-Roman France, is assumed by Donne as well as by Robert Parsons to have also written Vindiciae contra Tyrannos (1579), but some modern critics contest the latter authorship: see "Commentary," Pseudo-Martyr, p. 272.

8. Donne makes no reference to the Coronation Oath of the kings of France which required them to defend Catholicism, a subject that, because of its implications for religious tolerance, he could have treated in the unwritten thirteenth chapter of Pseudo-Martyr on France.

9. For a brief description of the Venetian conflict and the negotiations for peace: PseudoMartyr, pp. 15, 11-18, and "Introduction," p. xxvii.

10. "Introduction," Pseudo-Martyr, pp. xxvi-xxvii, and p. xlvii.

11. The Parlement of Paris in January 1595 expelled the Jesuits, an expulsion which Henry tried to stop. He allowed them to return in 1603 . 
12. Duperron's letter appeared in Monita Politica, ad Sacri Romani Imperii Principes, de Immensa Curiae Romanae potentia moderanda (Frankfurt, 1609).

13. The Edict of Nantes of 1598 was not intended to be a permanent act of toleration but a temporary measure to allow the peaceful conversion of French Protestants to Catholicism, a question that Donne supposedly would have had to contend with in chapter thirteen: M. Turchetti. "Concorde ou tolérance? De 1562 à 1598," Revue Historique, 556 (October-December, 1985), 341-355. 